\title{
PENGGUNAAN GRAFIT BATU BATERAI SEBAGAI ALTERNATIF ELEKTRODA SPEKTROGRAFI EMISI
}

\author{
ARIF ARTADI $^{*}$, SUDARYO $^{*}$, ARYADI $\left.^{* *}\right)$ \\ *) Jurusan Teknokimia Nuklir STTN - BATAN \\ Jl. Babarsari Kotak Pos 6101 YKBB Yogyakarta 55281 \\ Telepon 0274-484085, 489716, Faksimili 0274-489715 \\ ${ }^{* *}$ Pustek Akselerator dan Proses Bahan-BATAN \\ Jl. Babarsari Kotak Pos 6101/YKBB Yogyakarta 55281 Telp. (0274) 488435
}

\begin{abstract}
Abstrak
KEMUNGKINAN PENGGUNAAN GRAFIT BATU BATERAI SEBAGAI ALTERNATIF ELEKTRODA SPEKTROGRAFI EMISI. Telah dilakukan analisis boron (B) dan kadmium (Cd) di dalam $\mathrm{U}_{3} \mathrm{O}_{8}$ dengan menggunakan elektroda grafit baterai bekas pada spektrografi emisi. Analisis dilakukan dengan metode DC-Arc, arus 10 Ampere, tegangan 220 Volt, waktu exposure 25 detik, jarak elektroda $2 \mathrm{~mm}$. Cuplikan diekstraksi menggunakan TBP-Kerosin dengan perbandingan $70: 30$ sebanyak $200 \mathrm{ml}$. Fasa air hasil ekstraksi diteteskan pada elektroda dan dieksitasi. Intensitasnya dibandingkan dengan standarnya, maka diperoleh konsentrasi boron dan kadmium terukur dengan elektroda grafit spex industries masing-masing $0,07 \mathrm{ppm}$ dan $0,15 \mathrm{ppm}$, yang terukur dengan elektroda grafit baterai bekas adalah $0,21 \mathrm{ppm}$ dan $0,14 \mathrm{ppm}$. Dari hasil tersebut, dapat disimpulkan bahwa elektroda grafit batu baterai tidak dapat digunakan sebagai alternatif elektroda pengganti pada spektrografi emisi.
\end{abstract}

Kata kunci : Spektrografi emisi, grafit, boron, kadmium, elektroda.

\begin{abstract}
THE USING OF USED BATTERY AS ALTERNATIVE ELECTRODE FOR EMISSION SPECTROGRAPHY. Analysis of boron (B) and cadmium (Cd) in $\mathrm{U}_{3} \mathrm{O}_{8}$ has been carried out by using used battery electrode at emission spectrography method. Analysis was done with the DC-Arc method, 10 Ampere current, 220 voltage, 25 second exposure time, and $2 \mathrm{~mm}$ electrode apart. The sample was extracted using TBP-Kerosin with the ratio of $70: 30$ volume of $200 \mathrm{ml}$. Water phase as the extraction result was dripped on electrode and excitated. Intensity of the samples were compared to its standard, then it was obtained boron and cadmium concentration in sample were $0.07 \mathrm{ppm}$ and $0.15 \mathrm{ppm}$ respectively. The analysis result of boron and cadmium concentration in the sample using battery electrode were $0.21 \mathrm{ppm}$ and $0.14 \mathrm{ppm}$ respectively.
\end{abstract}

Keywords : Emission spectrography, graphite, boron, cadmium, electrode.

\section{PENDAHULUAN}

Bahan bakar nuklir uranium sangat penting diuji kualitasnya sebelum digunakan. Uranium yang digunakan di dalam reaktor nuklir harus mempunyai kemurnian 
yang sangat tinggi, terutama dari unsur yang mempunyai penampang lintang serapan terhadap neutron yang besar. ${ }^{[1,2]}$ Serbuk U3O8 adalah salah satu bahan baku untuk pembuatan elemen bahan bakar nuklir. ${ }^{[3]}$ Sebelum digunakan serbuk $\mathrm{U}_{3} \mathrm{O}_{8}$ tersebut harus melalui tahap uji kualitas bahan. Uji kualitas bahan tersebut diantaranya adalah analisis unsur takmurnian yang terdapat dalam bahan bakar tersebut. Untuk dapat digunakan sebagai bahan bakar nuklir, uranium harus memenuhi persyaratan, yaitu bebas atau sedikit mengandung unsur takmurnian yang dapat mengganggu efektifitas uranium. ${ }^{[4]}$ Pada tahap pemurnian dalam proses pembuatan bahan bakar uranium, akan dipisahkan beberapa unsur yang dapat mengganggu, biasanya disebut unsur takmurnian. Unsur-unsur itu antara lain boron, kadmium, unsur tanah jarang dan logam besi. ${ }^{[5]}$ Boron merupakan unsur non logam golongan III A, periode 2 dengan nomor atom 5, massa atom relatif 10,811g/mol, titik leleh $20760 \mathrm{C}$ dan titik didih 3927 oC. Penampang lintang untuk boron sebesar 755 barn. ${ }^{[5]}$ Kadmium termasuk unsur transisi, golongan II B, periode 5 dengan massa atom relatif $112,411 \mathrm{~g} / \mathrm{mol}$, dengan nomor atom 48 , berwarna putih keperakaan. Titik leburnya $321,07^{\circ} \mathrm{C}$ dan titik didihnya $767^{\circ} \mathrm{C}$. Penampang lintang untuk kadmium adalah 2.550 barn. ${ }^{[6]}$

Grafit adalah satu inti karbon yang merupakan konduktor listrik yang bisa digunakan sebagai material elektroda pada sebuah lampu listrik. ${ }^{[7]}$ Bahan grafit mempunyai keistimewaan seperti sifat mekanis seperti logam, ringan dan mempunyai sifat yang baik serta dari segi ekonomi bahan dasar grafit buatan tersedia melimpah dan murah. Banyak metode pembuatan grafit sintesis yang dikenal secara umum pembuatannya melalui tahap proses yaitu proses kalsinansi bahan mengandung unsur karbon menjadi bahan kokas, tahap pencampuran bahan kokas tersebut dengan bahan pengikat, pencetakan, pemanggangan dan grafitisasi. Sebagai contoh adalah kokas petroleum (petroleum coke) kokas terkalsinasi (calsine coke) dan kokas mentah (green coke). Grafit artificial dapat dihasilkan dari proses pemanasan bertahap bahan baku campuran calsine coke dan Tar Pitch, tahap pertama adalah tahap pemanggang $900^{\circ} \mathrm{C}$ diperoleh grafit Eurbo statik pada tahap grafitisasi 1 pemanasan mencapai suhu $1800^{\circ} \mathrm{C}$ dan akan menghasilkan grafit dengan stuktur kristal. Tahap selanjutnya grafitisasi 2 yang dipanaskan dengan suhu $3000^{\circ} \mathrm{C}$ hingga stuktur kristal berubah menjadi heksagonal. ${ }^{[7,8]}$

Dalam analisis spektrografi emisi, sering digunakan elektroda grafit kemurnian tinggi sebagai wadah cuplikan. Selain elektroda grafit dapat pula digunakan elektroda logam seperti alumunium $(\mathrm{Al})$, tembaga $(\mathrm{Cu})$, perak $(\mathrm{Ag})$, dan juga besi (Fe). Bahkan untuk keperluan spesifik dapat juga digunakan logam platina (Pt) sebagai elektroda. ${ }^{[9]}$ Adapun syarat suatu elektroda grafit dapat digunakan sebagai alternatif pengganti elektroda grafit spex industries apabila persen perbedaan hasil analisis antara yang menggunakan elektroda tersebut jika dibandingkan dengan elektroda grafit spex industries lebih kecil dari atau sama dengan $2 \%(\leq 2 \%){ }^{[10]}$ 
Pada penelitian ini digunakan grafit dari batu baterai bekas sebagai elektroda baik anoda maupun katoda sebagai pengganti elektroda grafit buatan Spex Industry, Pemilihan penganti elektroda ini berdasarkan pada kenyataan bahwa semakin menipisnya persediaan elektroda grafit buatan Spex Ind. Alasan dipilihnya grafit dari batu baterai bekas sebagai bahan alternatif pengganti elektroda buatan Spekx Ind. adalah bahwa grafit dari batu baterai mempunyai sifat fisis yang hampir sama dengan elektroda grafit yaitu tahan pada suhu tinggi sehingga memungkinkan untuk analisis unsur dengan menggunakan alat spektrograf emisi, disamping untuk memanfaatkan barang yang sudah tidak terpakai menjadi barang yang sangat bermanfaat. Oleh sebab itu penelitian ini bertujuan untuk mengetahui kemungkinan penggunaan elektroda grafit batu bateri bekas sebagai alternatif, karena elektroda grafit buatan Spex Industri susah di dapat dipasaran dan mahal harganya.

Keuntungan menggunakan elektroda grafit antara lain adalah harganya relatif murah dibandingkan elektroda logam karena pemurnian grafit untuk elektroda lebih sederhana bila dibandingkan dengan pemurnian logam untuk dijadikan elektroda. Sedangkan kerugian atau kelemahan elektroda grafit terutama terbentuknya spektrum pita spektra sianogen pada pelat/film fotografi, hal ini mengganggu spektra unsur yang dianalisis, walaupun spektra grafit (carbon) sendiri tidak begitu kompleks. ${ }^{[1]}$

Spektografi Emisi adalah suatu alat yang dapat digunakan untuk menganalisis suatu unsur yang tidak dapat dibaca spektrofotometer berdasarkan tebal tipisnya garis spektra. Metode ini bersifat spesifik, peka dan dapat menganalisis secara simultan beberapa unsur dengan hanya memerlukan sedikit cuplikan yang diletakkan pada sumber eksitasi. ${ }^{[9]}$

Prinsip dasar analisis spektrografi emisi adalah apabila suatu unsur diletakkan dalam sumber energi pengeksitasi, maka elektron yang ada pada orbital paling luar pada atom tersebut akan tereksitasi ke tingkat energi elektron yang lebih tinggi. Keadaan tereksitasi tersebut merupakan keadaan yang tidak stabil, oleh karena itu akan kembali ke tingkat energi elektron semula dengan memancarkan sinar yang mempunyai panjang gelombang yang karakteristik dengan unsur yang bersangkutan. ${ }^{[12]}$

Prinsip kerja alat spektrografi emisi dapat dilihat pada Gambar 3. 


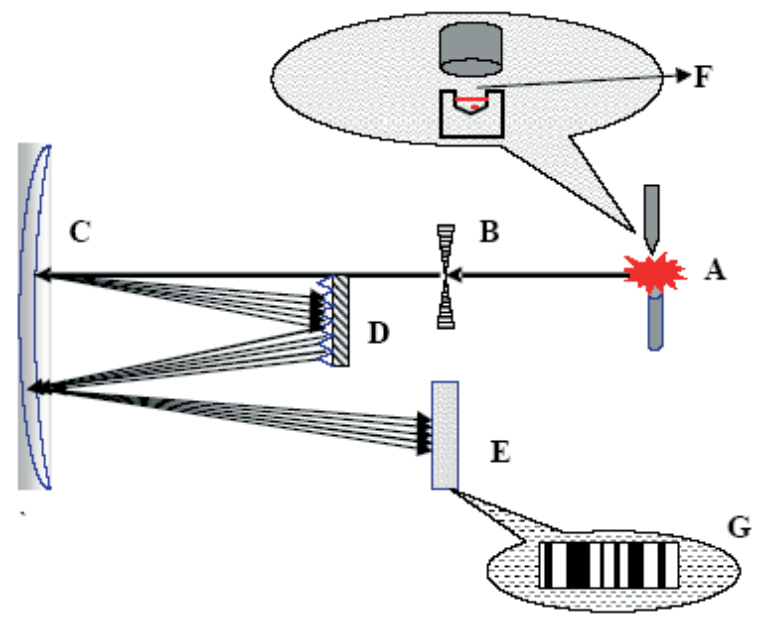

Gambar 3. Prinsip Kerja Alat Spektrograf Emisi

\begin{tabular}{lllrl}
\multicolumn{5}{c}{ Keterangan gambar } \\
$\mathrm{A}$ & : & Eksitasi Cuplikan & $\mathrm{E}$ & Film \\
$\mathrm{B}$ & : & Slite & $\mathrm{F}:$ & Tempat Cuplikan \\
$\mathrm{C}$ & : & Cermin & $\mathrm{G}:$ & Garis Spektrum Unsur \\
$\mathrm{D}$ & : & Gratting & &
\end{tabular}

Sumber eksitasi sangat berpengaruh terhadap bentuk dan intensitas emisi. Selain menyediakan energi yang cukup untuk mengubah bentuk cuplikan menjadi bentuk uap gas, sumber juga menyediakan eksitasi elektronik partikel-partikel elementer gas. Setiap spektrograf dilengkapi dengan media pengurai sinar radiasi yaitu prisma dan kisi difraksi (grating). Keduanya berfungsi menguraikan berkas sinar yang dihasilkan pada proses eksitasi menjadi garis-garis spektra yang terpisah satu dengan yang lainnya. Sebelum sinar radiasi menuju sistem optik, terlebih dahulu dilewatkan melalui celah atau diafragma yang berfungsi untuk mengatur lebar spektra serta mengatur tinggi garis spektra. Cuplikan atau sampel ditempatkan pada elektroda bawah sebagai anoda dan elektroda atas sebagai katoda. ${ }^{[7]}$

Analisis kualitatif terhadap spektrum dilakukan dengan membandingkan dengan spektrum standar yaitu spektrum suatu unsur yang telah diketahui, karena suatu unsur logam akan menghasilkan suatu spektrum dengan panjang gelombang yang karakteristik. Panjang gelombang spektrum boron dan kadmium masing-masing adalah 2497,73 $\AA$ dan 2288,02 $\AA$. Spektrum standar digunakan sebagai pembanding spektrum cuplikan, dan alat yang digunakan untuk membandingkan adalah Densitometer. Identifikasi positif jika minimal ada 3 garis spektrum yang posisinya tepat sama. Analisis kuantitatifnya berdasarkan densitas spektrum yang diukur menggunakan densitometer. Densitometer merupakan alat untuk mengukur derajat kehitaman garis spektrum pada pelat foto atau film. Dengan demikian densitas (D) merupakan dasar bagi pengukuran 
intensitas sinar, dan secara tidak langsung merupakan dasar bagi pengukuran konsentrasi cuplikan. Alat densitometer menunjukkan nilai transmitansi (T). Oleh karena yang ditunjukkan $\mathrm{T}$, maka diperlukan pengubahan nilai transmitansi menjadi densitas dengan rumus $\mathrm{D}=\log 1 / \mathrm{T}$. Densitas ini dapat dinyatakan dengan intensitas (I) menurut persamaan $D=\log \mathrm{I}_{\mathrm{o}} / \mathrm{I}_{\mathrm{t}}$.

Menurut hukum Lambert-Berr hubungan antara I dan konsentrasi (C) adalah $\log \mathrm{I}_{\mathrm{o}} / \mathrm{I}_{\mathrm{t}}=€ \mathrm{~b} \mathrm{c}$, disini $€$ adalah koefisien ekstingsi molar, $\mathrm{b}$ adalah panjang gelombang dan $\mathrm{c}$ adalah konsentrasi. Dari hukum tersebut dapat diketahui bahwa intensitas (I) sebanding dengan konsentrasi (C) dan kurvanya berupa garis linier. Kurva kalibrasi linier dengan persamaan $\mathrm{Y}=\mathrm{aX}+\mathrm{b}$ dapat dibuat dari intensitas suatu larutan standar yang telah diketahui konsentrasinya, dengan intensitas (I) sebagai Y dan konsentrasi sebagai X. Suatu cuplikan yang telah diketahui intensitasnya dari densitometer dapat dihitung konsentrasinya dengan memasukkan harga I ke dalam persamaan $\mathrm{Y}=\mathrm{aX}+\mathrm{b}$, dengan a sebagai slope dan $\mathrm{b}$ sebagai intersep yang dihitung dari larutan standar. ${ }^{[2]}$

\title{
METODE PENELITIAN
}

\section{Bahan}

Bahan yang digunakan adalah batu baterai bekas, serbuk $\mathrm{U}_{3} \mathrm{O}_{8}$, serbuk $\mathrm{CdO}$, serbuk $\mathrm{H}_{3} \mathrm{BO}_{3}$, asam Nitrat $65 \%$, asam Nitrat $3 \mathrm{M}$, asam Format (HCOOH), TBPKerosin 70-30, Akuades, Developer, fixer.

\begin{abstract}
Alat
Alat yang digunakan adalah unit analiser spektografi emisi, densitometer, neraca analitik Sartorius 2405, pengaduk magnetik, labu ekstraksi, beker gelas, labu takar, pipet volum, mikro pipet, pipet tetes, film toraks, elektroda grafit Spex Ind.
\end{abstract}

\section{Cara Kerja}

Teknik pembuatan elektroda grafit dari batu baterai bekas

Batu baterai bekas dibuka dan diambil grafit yang ada di dalam baterai tersebut. Untuk membuat anoda, grafit dicuci dan dikeringkan lalu dibuat lubang pada salah satu ujungnya dengan ukuran diameter lubang $4 \mathrm{~mm}$, kedalaman $6 \mathrm{~mm}$ dengan menggunakan alat pembubut yang ada di Balai Elektro Mekanik PTAPB. Katoda dibuat dengan cara grafit batu baterai bekas setelah dicuci, salah satu ujungnya dibuat runcing dengan alat peruncing.

\section{Pembuatan Larutan Standar Cd}

Larutan Cd 10 ppm dibuat dengan menimbang serbuk CdO sebanyak 0,001143 gram dan dilarutkan dengan asam nitrat $\left(\mathrm{HNO}_{3}\right)$ pekat sampai larut menggunakan pemanas listrik. Larutan tersebut ditambah akuades secara bertetes sampai unsur organik hilang. Larutan $\mathrm{CdO}$ dimasukkan ke dalam labu takar $100 \mathrm{~mL}$ dan ditambah aquades sampai tanda. Larutan standar dimasukkan ke dalam elektroda 
grafit dan elektroda grafit batu baterai menggunakan mikro pipet dengan variasi volume $10 \mu \mathrm{L} ; 25 \mu \mathrm{L} ; 50 \mu \mathrm{L} ; 100 \mu \mathrm{L} ; 200 \mu \mathrm{L} ; 400 \mu \mathrm{L} ; 600 \mu \mathrm{L} ; 800 \mu \mathrm{L}$ dan $1000 \mu \mathrm{L}$.

Pembuatan Larutan Standar B

Larutan standar B $10 \mathrm{ppm}$ dibuat dengan cara menimbang serbuk $\mathrm{H}_{3} \mathrm{BO}_{3}$ sebanyak 0,000564 gram, kemudian dilarutkan dengan asam nitrat $1 \mathrm{M}$ sampai larut. Larutan dimasukkan dalam labu takar $10 \mathrm{~mL}$ dan ditambah aquades sampai tanda. Larutan standar dimasukkan ke dalam elektroda grafit dan elektroda grafit batu baterai menggunakan mikro pipet dengan variasi volum $10 \mu \mathrm{L} ; 25 \mu \mathrm{L} ; 50 \mu \mathrm{L}$; $100 \mu \mathrm{L} ; 200 \mu \mathrm{L} ; 400 \mu \mathrm{L} ; 600 \mu \mathrm{L} ; 800 \mu \mathrm{L}$ dan $1000 \mu \mathrm{L}$.

Pembuatan Cuplikan

Kernel $\mathrm{U}_{3} \mathrm{O}_{8}$ sebanyak 10 gram dilarutkan dengan asam nitrat $\left(\mathrm{HNO}_{3}\right) 1 \mathrm{M}$ sampai larut menghasilkan larutan uranium nitrat. Larutan uranium nitrat yang dihasilkan disaring, filtratnya dimasukkan ke dalam labu takar $100 \mathrm{ml}$ ditambah air bebas mineral (ABM) hingga tanda batas dan digojok. Larutan uranium nitrat dimasukkan dalam corong pemisah, kemudian diekstraksi menggunakan TBPkerosin dengan perbandingan 70 : 30 sebanyak $200 \mathrm{~mL}$ untuk memisahkan fase air dan fase organiknya. Fase air hasil ekstraksi dimasukkan dalam elektroda grafit spex industries dan elektroda grafit batu baterai masing-masing sebanyak $600 \mu \mathrm{L}$.

\section{Proses Eksitasi}

Standar dan cuplikan dieksitasikan dengan menggunakan spektrografi emisi secara berurutan, dimulai dari standar dalam elektroda grafit dari volume yang terkecil, kemudian cuplikan dalam elektroda grafit. Setelah itu standar dalam elektroda grafit batu baterai diikuti cuplikan dalam elektroda grafit batu baterai. Kondisi eksitasi adalah sebagai berikut:

1. Grating : 590 groves $/ \mathrm{mm}$

2. Sumber arus : DC-Arc

3. Pre-Burn : 0 detik

4. Exposure : 25 detik

5. Arus : 10 Ampere

6. Jarak elektroda : $2 \mathrm{~mm}$

\section{Proses Pencucian film}

Hasil eksitasi yang terdapat dalam pelat film akan dapat dilihat dengan mencuci pelat film, yaitu dengan cara: pelat film direndam dalam developer selama 3 menit, kemudian direndam pelat film dalam fixer selama 3 menit, dicuci dan dibilas menggunakan air mengalir selama 3 menit, setelah itu pelat film dikeringkan.

Hasil yang didapat dari proses ini adalah spektrum garis yang terdapat di dalam pelat film, spektrum garis itu terdiri atas spektrum garis standar dan cuplikan. 


\section{Pengamatan spektrum}

Untuk analisis baik secara kualitatif maupun kuantitatif digunakan alat densitometer. Analisis kualitatif berdasarkan spektrum standar kadmium $(\mathrm{Cd})$ dan boron (B) diberbagai panjang gelombang, sedangkan analisis kuantitatif berdasarkan densitas atau persen transmitansi masing-masing spektrum unsur yang dianalisis dibandingkan dengan larutan standarnya.

\section{HASIL DAN PEMBAHASAN}

Semua analisis dilakukan dalam bentuk oksida karena lebih stabil sehingga sifat eksitasinya sama, baik untuk standar maupun untuk cuplikan. $\mathrm{U}_{3} \mathrm{O}_{8}$ adalah bentuk oksida yang lebih stabil pada suhu tinggi dibandingkan dengan bentuk $\mathrm{UO}_{2}$. Untuk mengubah $\mathrm{UO}_{2}$ menjadi $\mathrm{U}_{3} \mathrm{O}_{8}, \mathrm{UO}_{2}$ dilarutkan dengan asam nitrat $\left(\mathrm{HNO}_{3}\right)$ sampai larut, sehingga $\mathrm{UO}_{2}$ akan menjadi uranil nitrat $\left(\mathrm{UO}_{2}\left(\mathrm{NO}_{3}\right)_{2}\right)$. Larutan uranil nitrat dipanaskan mendekati kering kemudian ditambah asam format $(\mathrm{HCOOH})$ tetes demi tetes sampai larut untuk menghasilkan larutan uranil format $\left(\mathrm{UO}_{2}(\mathrm{COOH})_{2}\right)$. Larutan uranil format diuapkan dan dikalsinasi pada suhu $850{ }^{\circ} \mathrm{C}$ selama 3 jam. Serbuk $\mathrm{U}_{3} \mathrm{O}_{8}$ yang dihasilkan dari proses kalsinasi ini kemudian dianalisis menggunakan unit analiser spektrografi emisi. Analisis unsur takmurnian yang dilakukan dalam bentuk cair. Cuplikan yang diperoleh dengan melarutkan uranium oksida $\left(\mathrm{U}_{3} \mathrm{O}_{8}\right)$ dengan asam nitrat. Setelah uranium oksida larut, dilakukan ekstraksi menggunakan TBP-kerosin dengan perbandingan $70: 30$ menghasilkan fasa organik dan fasa air. Fasa air merupakan cuplikan yang akan dianalisis unsur takmurnian boron dan kadmiumnya.

Data Intensitas Larutan Standar Boron dan Cuplikan dalam Elektroda Grafit Spex Industries dengan Sumber Eksitasi DC Arc tertampil pada Tabel 1.

Tabel 1. Data Intensitas Larutan Standar Boron dan Cuplikan dalam Elektroda Grafit

\begin{tabular}{ccccc}
\multicolumn{5}{c}{ Spex Industries } \\
\hline No & Kode & $\begin{array}{c}\text { Massa } \\
(\mu \mathrm{g})\end{array}$ & $\begin{array}{c}\text { Transmitansi } \\
(\%)\end{array}$ & Intensitas \\
\hline 1 & Standar 1 & 0,10 & 67,5 & 0,171 \\
2 & Standar 2 & 0,25 & 65,5 & 0,183 \\
3 & Standar 3 & 0,50 & 65,2 & 0,185 \\
4 & Standar 4 & 1,00 & 58,8 & 0,231 \\
5 & Standar 5 & 2,00 & 51,1 & 0,292 \\
6 & Standar 6 & 4,00 & 41,5 & 0,382 \\
7 & Standar 7 & 6,00 & 32,4 & 0,489 \\
8 & Standar 8 & 8,00 & 26,6 & 0,575 \\
9 & Standar 9 & 10,00 & 21,0 & 0,678 \\
10 & Cuplikan 1 & & 62,0 & 0,208 \\
\hline
\end{tabular}

Dari Tabel 1 dapat dibuat grafik hubungan antara intensitas dengan massa larutan standar yang disajikan pada Gambar 1 . 


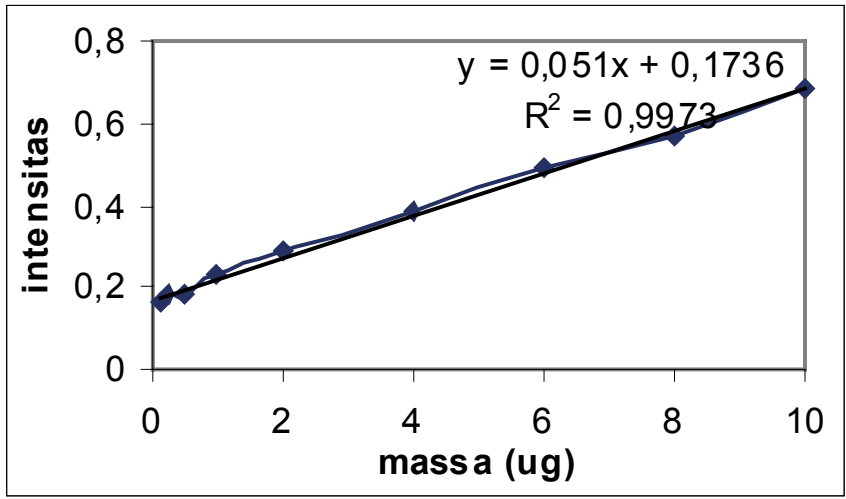

Gambar 1. Grafik Hubungan Antara Intensitas dan Massa Larutan Standar Boron dalam Elektroda Grafit Spex Ind.

Berdasarkan persamaan garis regresi jumlah unsur takmurnian boron pada cuplikan menggunakan elektroda grafit $=0,6667 \mu \mathrm{g}$.

konsentrasi boron dalam $600 \mu \mathrm{L}$ cuplikan $=\frac{\text { massa boron dalam sampel }}{\text { massa sampel mula }- \text { mula }}$

$$
=0,06667 \mu \mathrm{g} / \mathrm{g}=0,07 \mathrm{ppm}
$$

Data Intensitas Larutan Standar Boron dan Cuplikan dalam Elektroda Grafit Batu Baterai dengan Sumber Eksitasi DC Arc dapat dilihat pada Tabel 3.

Tabel 2. Data Intensitas Larutan Standar Boron dan Cuplikan dalam Elektroda Grafit Batu Baterai

\begin{tabular}{ccccc}
\hline No & Kode & $\begin{array}{c}\text { Massa } \\
(\mu 1)\end{array}$ & $\begin{array}{c}\text { Transmitansi } \\
(\%)\end{array}$ & Intensitas \\
\hline 1 & Standar 1 & 0,10 & 64,3 & 0,192 \\
2 & Standar 2 & 0,25 & 61,2 & 0,213 \\
3 & Standar 3 & 0,50 & 57,8 & 0,238 \\
4 & Standar 4 & 1,00 & 55,0 & 0,260 \\
5 & Standar 5 & 2,00 & 46,7 & 0,331 \\
6 & Standar 6 & 4,00 & 35,0 & 0,456 \\
7 & Standar 7 & 6,00 & 27,8 & 0,556 \\
8 & Standar 8 & 8,00 & 22,5 & 0,648 \\
9 & Standar 9 & 10,00 & 15,4 & 0,812 \\
10 & Cuplikan 1 & & 47,0 & 0,328 \\
\hline
\end{tabular}

Dari Tabel 2 dapat dibuat grafik hubungan antara intensitas dengan massa larutan standar yang disajikan pada Gambar 2 . 


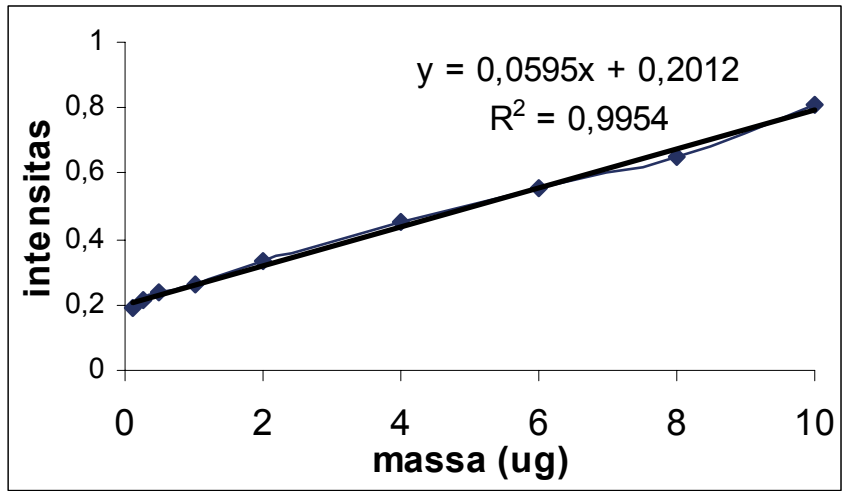

Gambar 2. Grafik Hubungan Antara Intensitas dan Massa Larutan Standar Boron Dalam Elektroda Grafit Batu Baterai

Berdasarkan persamaan garis regresi jumlah unsur takmurnian boron pada cuplikan menggunakan elektroda grafit $=2,131 \mu \mathrm{g}$.

konsentrasi boron dalam $600 \mu \mathrm{L}$ cuplikan $=\frac{\text { massa boron dalam sampel }}{\text { massa sampel mula }- \text { mula }}$

$$
=\frac{2,131 \mu \mathrm{g}}{10 \mathrm{~g}}=0,2131 \mu \mathrm{g} / \mathrm{g}=0,21 \mathrm{ppm}
$$

Data Intensitas Larutan Standar Kadmium dan Cuplikan dalam Elektroda Grafit Spex Industries dengan Sumber Eksitasi DC Arc dapat dilihat pada Tabel 3.

Tabel 3. Data Intensitas Larutan Standar Kadmium dan Cuplikan dalam Elektroda Grafit

\begin{tabular}{lcccl}
\multicolumn{5}{c}{ Spex Industries } \\
\hline No & Kode & $\begin{array}{c}\text { Massa } \\
(\mu \mathrm{g})\end{array}$ & $\begin{array}{c}\text { Transmitansi } \\
(\%)\end{array}$ & Intensitas \\
\hline 1 & Standar 1 & 0,10 & 96,1 & 0,017 \\
2 & Standar 2 & 0,25 & 95,6 & 0,020 \\
3 & Standar 3 & 0,50 & 91,4 & 0,039 \\
4 & Standar 4 & 1,00 & 89,8 & 0,047 \\
5 & Standar 5 & 2,00 & 86,2 & 0,064 \\
6 & Standar 6 & 4,00 & 81,0 & 0,092 \\
7 & Standar 7 & 6,00 & 74,2 & 0,130 \\
8 & Standar 8 & 8,00 & 69,1 & 0,161 \\
9 & Standar 9 & 10,00 & 64,0 & 0,194 \\
10 & Cuplikan 1 & & 89,3 & 0,049 \\
\hline
\end{tabular}

Dari Tabel 3 dapat dibuat grafik hubungan antara intensitas dengan massa larutan standar yang disajikan pada Gambar 3. 


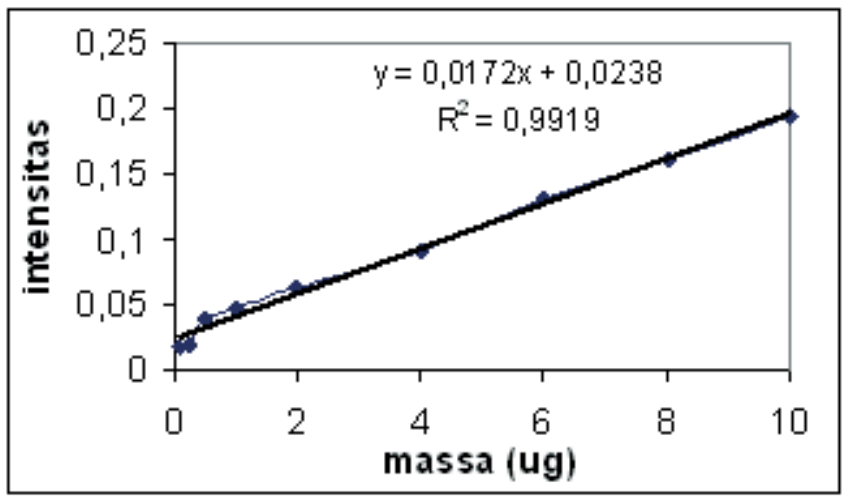

Gambar 3. Grafik Hubungan Antara Intensitas dan Massa Larutan Standar Kadmium dalam Elektroda Grafit Spex Ind

Berdasarkan persamaan garis regresi jumlah unsur takmurnian kadmium pada cuplikan menggunakan elektroda grafit $=1,4738 \mu \mathrm{g}$.

konsentrasi kadmium dalam $600 \mu \mathrm{L}$ cuplikan $=\frac{\text { massa boron dalam sampel }}{\text { massa sampel mula }- \text { mula }}$

$$
=\frac{1,4738 \mu \mathrm{g}}{10 \mathrm{~g}}=0,14738 \mu \mathrm{g} / \mathrm{g}=0,15 \mathrm{ppm}
$$

Data Intensitas Larutan Standar Kadmium dan Cuplikan dalam Elektroda Grafit Batu Baterai dengan Sumber Eksitasi DC Arc dapat dilihat pada Tabel 4.

Tabel 4. Data Intensitas Larutan Standar Kadmium dan Cuplikan dalam Elektroda Grafit Batu Baterai

\begin{tabular}{ccccc}
\hline No & Kode & $\begin{array}{c}\text { Massa } \\
(\mu \mathrm{g})\end{array}$ & $\begin{array}{c}\text { Transmitansi } \\
(\mathbf{\%})\end{array}$ & Intensitas \\
\hline 1 & Standar 1 & 0,10 & 97,2 & 0,012 \\
2 & Standar 2 & 0,25 & 94,2 & 0,026 \\
3 & Standar 3 & 0,50 & 91,7 & 0,038 \\
4 & Standar 4 & 1,00 & 90,8 & 0,042 \\
5 & Standar 5 & 2,00 & 88,0 & 0,056 \\
6 & Standar 6 & 4,00 & 81,0 & 0,092 \\
7 & Standar 7 & 6,00 & 74,0 & 0,131 \\
8 & Standar 8 & 8,00 & 69,1 & 0,161 \\
9 & Standar 9 & 10,00 & 63,5 & 0,197 \\
10 & Cuplikan 1 & & 90,0 & 0,046 \\
\hline
\end{tabular}

Dari Tabel 4 dapat dibuat grafik hubungan antara intensitas dan massa larutan standar yang disajikan pada Gambar 4 berikut. 


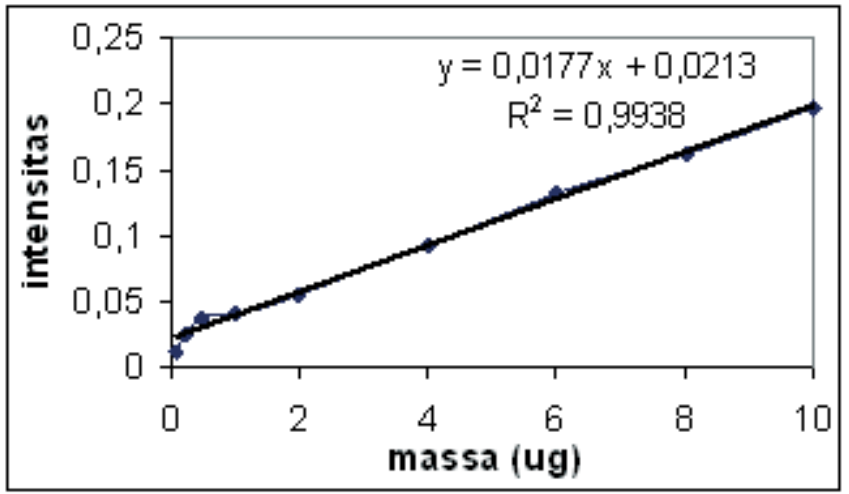

Gambar 4. Grafik Hubungan Antara Intensitas dan Massa Larutan Standar Kadmium dalam Elektroda Grafit Batu Baterai

Berdasarkan persamaan garis regresi jumlah unsur takmurnian kadmium pada cuplikan terukur menggunakan elektroda grafit adalah 1,3932 $\mu \mathrm{g}$.

konsentrasi kadmium dalam $600 \mu \mathrm{L}$ cuplikan $=\frac{\text { massa boron dalam sampel }}{\text { massa sampel mula }- \text { mula }}$

$$
=\frac{1,3932 \mu \mathrm{g}}{10 \mathrm{~g}}=0,13932 \mu \mathrm{g} / \mathrm{g}=0,14 \mathrm{ppm}
$$

Unsur takmurnian boron dan kadmium merupakan salah satu unsur pengotor yang terdapat di dalam bahan bakar nuklir sebenarnya sudah tidak mungkin lagi dipisahkan dari matriksnya, karena sudah melalui ekstraksi dengan solven TBPkerosin yang mampu mengekstraksi uranium dalam bentuk nitrat hampir $100 \%$.

Analisis cuplikan menggunakan sumber eksitasi DC-Arc karena sensitivitasnya lebih tinggi jika dibandingkan dengan sumber eksitasi lainnya dan dapat digunakan untuk segala macam bentuk cuplikan. Selain itu sumber eksitasi ini dapat menghasilkan suhu yang tinggi sehingga diharapkan unsur takmurnian tersebut dapat tereksitasi semua. Namun demikian, sumber eksitasi DC-Arc akan menghasilkan spektrum Sianogen yang dapat mengganggu pada saat penentuan dan pengukuran garis spektra yang ditentukan. Dipilih sumber eksitasi DC-Arc karena elektroda grafit batu baterai yang digunakan tidak meleleh, karena grafit batu baterai tahan pada suhu tinggi. Apabila sumber eksitasinya menggunakan sumber eksitasi spark sebenarnya elektroda grafit batu baterai tidak rusak, tetapi konsentrasi dari standar tidak terdeteksi oleh alat karena tingkat sensitivitasnya lebih rendah daripada sumber eksitasi DC-Arc.

Oleh karena itu diperlukan pemilihan sumber eksitasi yang tepat agar diperoleh hasil yang baik. Sumber eksitasi pada spektrografi emisi berfungsi untuk mengubah bentuk cuplikan menjadi bentuk uap yang selanjutnya mengeksitasi atom sehingga terjadi transisi elektron dalam atom tersebut untuk 
menjadi atom yang stabil, maka dalam perjalanan atom menjadi stabil akan melepaskan sebagian energinya dalam bentuk pancaran radiasi.

Analisis boron dan kadmium dilakukan berdasarkan standar yang menghasilkan suatu persamaan garis, kemudian persamaan garis tersebut digunakan untuk analisis dalam cuplikan sehingga diperoleh konsentrasinya. Untuk konsentrasi yang sangat rendah kalau kondisinya tidak sesuai maka unsur takmurnian yang tereksitasi sangat sedikit. Akibatnya intensitas yang diperoleh juga akan sangat kecil, begitu juga sebaliknya kalau konsentrasinya cukup tinggi maka intensitas yang dihasilkan juga akan cukup tinggi.

Spektra atom dalam spektrografi emisi setelah melalui sistem optik akan terekam pada film/plat fotografi. Spektra atom tersebut dapat dilihat setelah dilakukan pencucian film menggunakan larutan developer dan fiksatif. Pencucian film dilakukan didalam ruang gelap atau ruang yang disinari lampu infra merah, karena emulsi plat fotografi sangat peka terhadap sinar. Larutan developer berfungsi untuk mereduksi $\mathrm{Ag}^{+}$menjadi $\mathrm{Ag}$ yang akan mempermudah pada proses pembacaan film. Setelah melewati pencucian developer maka selanjutnya dicuci dengan larutan fixer yang bermanfaat untuk memperoleh gambar permanen serta menghilangkan kelebihan emulsi perak halida yang tidak terkena sinar radiasi. Selanjutnya dicuci dengan air mengalir agar emulsi perak halida yang masih menempel pada plat film hilang.

Hasil dari plat film tersebut berupa spektra garis yang dapat diamati dengan alat densitometer dalam bentuk persen transmitansi $(\% \mathrm{~T})$ dari masingmasing larutan standar dan cuplikan yang kemudian dikonversi menjadi intensitas dengan rumus $\mathrm{I}=\log 1 / \mathrm{T}$ karena konsentrasi unsur dapat ditentukan berdasarkan pengukuran intensitas garis spektra unsur tersebut. Intensitas yang diperoleh dihubungkan dengan konsentrasi larutan standar, sehingga menghasilkan kurva kalibrasi antara massa dengan massa. Persamaan garis regresi linier yang diperoleh adalah sebagai berikut:

1. Standar boron dengan elektroda grafit spex industries:

$$
\mathrm{Y}=0,051 \mathrm{X}+0,1736
$$

2. Standar boron dengan elektroda grafit batu baterai:

$$
\mathrm{Y}=0,0595 \mathrm{X}+0,2011
$$

3. Standar kadmium dengan elektroda grafit spex industries:

$$
\mathrm{Y}=0,0172 \mathrm{X}+0,0238
$$

4. Standar kadmium dengan elektroda grafit batu baterai:

$$
\mathrm{Y}=0,0177 \mathrm{X}+0,0211
$$

Persamaan garis regresi linier ini digunakan untuk menghitung konsentrasi boron dan kadmium dalam cuplikan. Nilai intensitas dari cuplikan disubstitusikan kedalam nilai $\mathrm{Y}$, maka akan diperoleh nilai $\mathrm{X}$ sebagai konsentrasi. Hasil dari perhitungan ditunjukkan pada tabel di bawah ini. 
Tabel 5. Hasil Perhitungan Konsentrasi Boron dan Kadmium dalam Cuplikan

\begin{tabular}{cllcc}
\hline No & $\begin{array}{l}\text { Unsur yang } \\
\text { Ditentukan }\end{array}$ & $\begin{array}{c}\text { Elektroda yang } \\
\text { digunakan }\end{array}$ & $\begin{array}{c}\text { Massa } \\
(\mu \mathrm{g})\end{array}$ & $\begin{array}{c}\text { Konsentrasi } \\
(\mathrm{ppm})\end{array}$ \\
\hline 1 & Boron & Grafit spex industries & 0,6667 & 0,07 \\
2 & Boron & Grafit batu baterai & 2,1310 & 0,21 \\
3 & Kadmium & Grafit spex industries & 1,4378 & 0,15 \\
4 & Kadmium & Grafit batu baterai & 1,3932 & 0,14 \\
\hline
\end{tabular}

Perhitungan persen perbedaan antara menggunakan elektroda grafit Spex Industries dan elketroda grafit Batu Baterai. Adalah sebagai berikut :

Persen perbedaan pada penentuan konsentrasi boron :

diketahui :

1. konsentrasi boron dalam grafit spex industries $=0,07 \mathrm{ppm}$

2. konsentrasi boron dalam grafit batu baterai $=0,21 \mathrm{ppm}$ sehingga akan diperoleh :

$$
\begin{aligned}
\text { persen perbedaan } & =\frac{\text { selisih konsentrasi boron }}{\text { konsentrasi dalam grafit spex industries }} \times 100 \% \\
& =\frac{(0,21-0,07) \mathrm{ppm}}{0,07 \mathrm{ppm}} \times 100 \%=200 \%
\end{aligned}
$$

Persen perbedaan pada penentuan konsentrasi kadmium :

diketahui :

1. konsentrasi kadmium dengan grafit spex industries $=0,15 \mathrm{ppm}$

2. konsentrasi kadmium dengan grafit batu baterai $=0,14 \mathrm{ppm}$ sehingga akan diperoleh :

$$
\begin{aligned}
\text { persen perbedaan } & =\frac{\text { selisih konsentrasi kadmium }}{\text { konsentrasi dalam grafit spex industries }} \times 100 \% \\
& =\frac{(0,15-0,14) \mathrm{ppm}}{0,14 \mathrm{ppm}} \times 100 \%=7,14 \%
\end{aligned}
$$

Hasil yang diperoleh menunjukkan bahwa konsentrasi boron dan kadmium lebih kecil dari 0,5 ppm sebagai batas maksimum keberadaan boron dan kadmium dalam bahan bakar nuklir. Konsentrasi boron dan kadmium tersebut masih bisa diterima karena konsentrasinya masih di bawah batasan maksimum yang diijinkan sehingga memenuhi persyaratan sebagai bahan bakar nuklir. Apabila konsentrasi boron dan kadmium masih lebih besar dari batasan maksimum yang diijinkan maka bahan bakar nuklir tersebut sebelum digunakan harus dilakukan proses pemurnian terlebih dahulu. 
Penentuan unsur takmurnian tersebut sebenarnya merupakan metode untuk menguji elektroda grafit batu baterai bisa digunakan sebagai pengganti elektroda grafit pada spektrografi emisi. Dari perhitungan penentuan konsentrasi boron dengan menggunakan elektroda grafit spex industries dan grafit batu baterai sebesar 0,07 ppm dan 0,21 ppm. Sedangkan konsentrasi kadmium menggunakan elektroda grafit spex industries dan grafit batu baterai sebesar $0,15 \mathrm{ppm}$ dan 0,14 ppm. Dari penggunaan elektroda grafit spex industries jika dibandingkan dengan grafit batu baterai untuk penentuan unsur takmurnian boron dan kadmium terjadi perbedaan yang signifikan terutama untuk penentuan unsur takmurnian boron dengan persen perbedaan $200 \%$.

Oleh karena itu, agar dapat digunakan sebagai elektroda alternatif pengganti elektroda grafit pada spektrografi emisi perlu dilakukan penelitian lanjutan untuk menentukan penyebab perbedaan hasil analisis yang signifikan.

\section{KESIMPULAN}

Dari penelitian kemungkinan penggunaan batu baterai sebagai alternatif pengganti elektroda grafit pada spektrografi dengan menentukan unsur takmurnian boron (B) dan kadmium (Cd) dalam $\mathrm{U}_{3} \mathrm{O}_{8}$ dapat diambil kesimpulan sebagai berikut:

1. Sumber eksitasi yang digunakan adalah sumber eksitasi DC-Arc karena elektroda grafit batu baterai tidak meleleh atau tahan terhadap suhu tinggi sehingga dengan sumber eksitasi tersebut akan diperoleh sensitivitas yang lebih tinggi daripada sumber eksitasi lainnya.

2. Konsentrasi unsur takmurnian boron (B) dan kadmium $(\mathrm{Cd})$ dalam $\mathrm{U}_{3} \mathrm{O}_{8}$ dengan menggunakan elektroda grafit spex industries masing-masing sebesar 0,07 ppm dan 0,15 ppm.

3. Konsentrasi unsur takmurnian boron (B) dan kadmium (Cd) dalam $\mathrm{U}_{3} \mathrm{O}_{8}$ dengan menggunakan elektroda grafit batu baterai masing-masing sebesar 0,21 ppm dan 0,14 ppm.

4. Persen perbedaan pada penentuan konsentrasi boron sebesar $200 \%$, sedangkan persen perbedaan pada penentuan konsentrasi kadmium sebesar $7,14 \%$, sehingga grafit batu baterai bekas belum dapat digunakan sebagai alternatif.

\section{DAFTAR PUSTAKA}

1. BENEDICT, M., 1981, Nuclear Chemical Engineering, McGraw Hill Inc, USA.

2. COTTON, F.A.;1990, Kimia Anorganik Dasar, UI-Press, Jakarta

3. http://id.wikipedia.org/wiki/bahan bakar nuklir

4. AKHADI, M.,2000, "Uranium”, makalah disampaikan dalam Presentasi Ilmiah, Badan Tenaga Nuklir Nasional, Jakarta, Oktober 2000.

5. http://en.wikipedia.org/wiki/boron 
6. http://en.wikipedia.org/wiki/kadmium

7. WILlIS, R., 1989, Kimia Inti, Depdikbud Dirjen Pendidikan Tinggi Proyek Pengembangan Lembaga Pendidikan Tenaga Kependidikan: Jakarta.

8. SUKARNA, I., 2003, Kimia Inti, Jurusan Pendidikan Kimia FMIPA Universitas Negeri Yogyakarta: Yogyakarta.

9. RUKIHATI, 1986, "Spektrografi Emisi”, Badan Tenaga Atom Nasional Pusat Pendidkan Dan Latihan: Yogyakarta.

10. SIMBOLON, S. dan ARYADI, 1980, “Analisis Kemurnian Uranium Sebagai Bahan Bakar Nuklir”, Buletin Batan, No 4, BATAN: Jakarta.

11. http://www.elektroindonesia.com/elektro/ener33a.html

12. ERTHERINGTON, H., 1958, Nuclear Engineering Handbook. 
